\title{
Creating Charisma Online: The Role of Digital Presence in the Formation of
}

Religious Identity

\section{Caroline Tee}

The Faraday Institute for Science and Religion

St Edmund's College

Cambridge

CB3 0BN

ct500@cam.ac.uk

Caroline Tee holds a PhD in Social Anthropology from the University of Bristol, and is the author of The Gülen Movement in Turkey: The Politics of Islam and Modernity (London: I.B. Tauris, 2016). She is Research Associate at the Faraday Institute for Science and Religion in Cambridge. From September 2018, she will be Senior Lecturer in the Department of Theology and Religious Studies at the University of Chester.

\section{$\underline{\text { Abstract }}$}

This article investigates the construction and transmission of charisma through online channels, and its role in the formation of religious identities. Mindful of Max Weber's observation that charisma inhabits the relationship between a leader and their followers, I argue for a critical reappraisal of the theoretical model in light of the ubiquity in the $21^{\text {st }}$ century of new, virtual forms of social encounter. I focus my analysis on the Christian creationist movement in the USA, and particularly on an influential leader called Ken Ham. Using digital ethnographic methods, I show how Ham constructs charisma online, and how a virtual community forms itself around his charismatic claims. I illustrate how this virtual community intersects with offline worlds, and suggest that the theme park attractions that Ham's organisation runs (Creation Museum, Ark Encounter) are imbued with deflected charisma by virtue of their association with his online avatar.

Keywords: Max Weber, creationism, charisma, digitisation, materiality.

Charisma, as Max Weber conceived it, is alive and well in the digital age. It manifests itself in high-profile political and religious leaders across the globe, ranging from US President Donald Trump to the controversial Turkish imam Fethullah Gülen. Such charismatic leaders are highly adept at communicating with their followers, and the wider world, through virtual media. President Trump, for example, is well known for his proclivity to address the world through the medium of Twitter, and Fethullah Gülen communicates with his global following via a weekly online video sermon. ${ }^{i}$

The new opportunities as well as constraints presented by the Internet age raise a series of important questions vis-à-vis Weber's theory of charisma. This is because the theory is concerned as much with the processes by which charisma is created as 
with the particular signs of its manifestation (Weber [1922] 1968). Rather than existing as an innate quality within an individual, charisma inhabits the dynamic relationship between a leader and their followers: in order to survive, it is dependent on devotees' continued recognition and endorsement of their leader's charismatic mission.

How, though, are the processes of charisma's creation disrupted or reborn when it is operational online, and when followers are virtual or even anonymous? In what ways is charisma transformed, and potentially commodified and marketized, in these virtual scenarios? And to what extent does online charisma interact with offline worlds? Despite an increasingly comprehensive literature on online religion (Brasher 2001; Campbell 2013; Gillespie et al 2013; Howard 2011), the question of charisma's metamorphosis in the age of the Internet remains remarkably under-explored. ${ }^{\text {ii }}$ Scholars of contemporary religion have applied Weber's theory of charisma to the modern world, but these investigations have mostly been concerned with pre-digital media as the vehicle for its transmission: the ability of Oral Roberts (1918-2009), for example, to harness the potential of radio in the service of his ministry has been well documented by Anderson Blanton (2015). In Blanton's study, the radio - as well as other material objects such as prayer cloths - are revealed as conduits for charismatic spiritual encounter and physical healing. Here, the esoteric experiences of the individual are foregrounded: the purpose of the radio is to connect the individual to the charisma of the preacher, and to serve as a conduit for the transmission of extraordinary spiritual power that effects personal encounter and change.

There is a qualitative difference between the function of the radio in Blanton's ethnography and the use of digital media in the analysis that follows. Digital media is far more varied in scope than the radio as a medium of communication, and in what follows I explore the novel ways in which charisma manifests itself in light of the particular opportunities afforded it by the online world. I am interested first and foremost in the ability of the Internet to channel charisma in such a way that connects individuals to one another and to a wider moral and religious cause. My focus therefore moves away from esotericism and personal religious encounter, and towards an analysis of digital technology vis-à-vis its potential to construct charismatic 
'imagined communities' (Anderson 1983), based on shared commitment to a religious agenda.

In my exploration into the making of online charisma, I focus on a phenomenon that is as political as it is religious - the young earth creationist movement in the United States (Berkman and Plutzer 2010, McCalla 2013, Numbers 1993). Born out of the Christian Fundamentalist movement that emerged in the early $20^{\text {th }}$ century, young earth creationism relies on a literalistic reading of the Biblical origins narrative in the Book of Genesis. Accordingly, it rejects modern scientific consensus on evolution and the age of the earth (c. 4.5 billion years), positing instead that God created the entire material universe in its present form in six literal days between only 6,000 and 10,000 years ago. Creationism is closely associated with a conservative Protestant constituency, but it has considerable currency across American society. ${ }^{\text {iii }}$

In what follows, I investigate how creationist leaders in the United States construct charisma online and utilise the Internet to maximise the power of their cause. The focus of my analysis is Ken Ham (b.1951), the highest profile creationist leader in the USA today and the founding president of a multi-million dollar organisation called Answers in Genesis (AIG) (Bielo 2014; Harding 2000; Numbers 1993; Trollinger and Trollinger 2016). Besides theme park-style attractions that showcase young earth creationism, AIG pro-actively disseminates creationist ideology via a range of digital media, all of which foreground the personality of Ken Ham. Through an online ethnographic investigation of Ham and AIG, it is my intention to provide a starting point for a discussion of digital charisma in its broader context, and therefore to contribute to scholarly interrogations of other high profile leaders and their ability to attract global followings through virtual media.

\section{$\underline{\text { Weber and Charisma }}$}

Since the publication of Economy and Society in 1922, Max Weber's theory of charisma has redirected sociological approaches to the study of leadership in the modern world (Derman 2012; Gerth and Wright Mills 2009; Lindholm 2002; Potts 2009; Roth and Wittich 1968; Stutje 2012). The term "charisma" has become ubiquitous as a vernacular idiom, matched perhaps only by Freud's notion of the 
"ego" in making the transfer so successfully from the academic to the popular lexicon (Joosse 2014, 267). In everyday parlance the word has a broader and more amorphous meaning than in Weber's definition, and is usually something akin to "charm", "magnetism", and always, in some way, "attractiveness". In the Weberian sense, however, charisma is defined much more specifically, as:

[...] a certain quality of an individual personality, by virtue of which he is considered extraordinary and treated as endowed with supernatural, superhuman, or at least specifically exceptional powers or qualities. These are such as are not accessible to the ordinary person, but are regarded as of divine origin or as exemplary, and on the basis of them the individual concerned is treated as a "leader". (Weber in Roth and Wittich 1968, 242)

Charisma is not originally a Weberian construct, but was adapted from its earlier theological meaning in the context of the New Testament, wherein it refers to the communal "gift of grace" bestowed upon the early Church (Potts 2009, 24-51). In the Weberian imaginary, however, charisma is transferred from religious to non-religious and even political contexts and, crucially, it is ascribed to an individual rather than the community. Charismatic leadership is primarily dependent on qualities associated directly with the individual himself or - more rarely - herself. It is identified as an alternative to other leadership styles that Weber names 'traditional' and 'rationallegal', both of which are inherently bureaucratic (Gerth and Wright Mills 2009). By contrast, in the sense that it operates outside the usual structures of hierarchical accountability, charisma is non-bureaucratic and definitively anti-rational (Roth and Wittich 1968, 244). These categories are not, nonetheless, mutually exclusive, and it is possible for a single leader or leadership system to employ more than one style simultaneously. In the analysis of Ken Ham that follows, for example, it becomes clear that charisma can be successfully employed in the defence of traditional social and religious values.

Despite its paradigmatic quality, Weber's theory of charisma is fragmentary and incomplete. It is therefore open to differing interpretations, and its reception in the scholarly literature has been varied. It faced criticism from Pierre Bourdieu, whose materialist analysis repudiated the idea of charisma existing as an innate presence or essence, and led him to accuse Weber of essentialism (Bourdieu in Lash and Whimster, 1987). Yet Weber was clear that he did not conceive of charisma as 
existing independently or operating under any kind of agency of its own. Rather, as mentioned above, he pointed to the relationship between a leader and his followers as the primary site in which charisma is constructed, affirmed and sustained, through a perpetually dynamic and bi-lateral process. Accordingly, Weber can state:

\footnotetext{
The holder of charisma seizes the task that is adequate for him and demands obedience and a following by virtue of his mission. His success determines whether he finds them. His charismatic claim breaks down if his mission is not recognised by those to whom he feels he has been sent. (Weber in Gerth and Wright Mills, 2009)
}

Without the approval of his followers, the charismatic leader's claim collapses. Indeed, unless the leader can continually demonstrate evidence of charisma - be it through miraculous acts, oratorical power or other claims to extraordinariness - which is compelling to followers, then the charismatic mantle dissolves. Welskopp has called this a "relationship of mutual dependency" and states that, "it is as inebriating as a habit-forming drug” (Welskopp in Stutje, 2012). ${ }^{\text {iv }}$

\section{$\underline{\text { Ken Ham and Answers in Genesis }}$}

Ken Ham is an evangelical Christian preacher who moved to the United States from his native Australia in the 1980s and who has since been a major impetus behind much organised American young earth creationism (Bielo 2014; Trollinger and Trollinger 2016). He began his career working alongside fellow-creationist Henry M. Morris (d.2006) at the Institute for Creation Research, headquartered today in Dallas, Texas (Numbers 1993). Morris was one of the founding fathers of organised creationism in the USA. In 1961, he co-authored a booked entitled The Genesis Flood, which would mark a milestone in the emergence of young earth creationism as an organised movement with recognisable leaders. Morris went on to found the ICR in 1972 as the first creationist institution in the USA, cementing creationism as an ideology with an established public presence. When Ham arrived in the USA in the 1980s, he therefore found a sympathetic creationist constituency already in place and well attuned to hear his message.

Ham moved away from the ICR to establish Answers in Genesis (AIG) in 1994, establishing its headquarters in Kentucky. In 2007, AIG opened the Creation Museum (Bielo 2014 and forthcoming; Trollinger and Trollinger 2016), a family-friendly theme park that promotes young earth creationism, which was followed in 2016 by 
Ark Encounter, a life sized model of Noah's Ark. In addition to these physical sites, Ham is a prolific user of digital media for the promotion of AIG's central ideas, and there are three primary channels through which he operates online: public debates and sermons on YouTube; preaching videos and blogs accessible on the AIG website; and his frequent contributions (as many as ten posts daily, including regular "live video feeds") on two different social media platforms, Facebook and Twitter.

Ham has 282,014 followers on Facebook and 52,700 on Twitter. ${ }^{\mathrm{v}}$ These figures are comparable to the following attracted by evangelical preacher and fellow-creationist in the USA, Ray Comfort (519,040 on Facebook, 60,300 on Twitter). They are significantly smaller than those of major evangelical leaders such as Rick Warren and Joyce Meyer (5.3 and 11m on Facebook, 2.1 and 5.2m on Twitter), or political figures such as Donald Trump (24m on Facebook, 41m on Twitter). While major celebrity figures are exceptions, the general trend in the USA is for an individual's Facebook followings to be larger than their Twitter counterparts. This unequal balance reflects the larger market share of the former in the USA (214m Facebook users compared to $67 \mathrm{~m}$ on Twitter). On average, Ham's posts on Facebook attract between 200-1,500 responses ('likes' and equivalents), and his posts on Twitter between 100-300.

Ham is not the only user of digital media within AIG, but rather numerous members of its staff contribute to the blogs, video-blogs, written articles and books that are promoted across the spectrum of its digital platforms. Indeed, while Ham is the founding director of AIG and occupies its most prominent public role, the organisation behind him is large in scale and relies on the participation of a considerable staff in order to operate. However, no other senior staff member at AIG has a significant public presence in their own right: it is Ken Ham alone who maintains celebrity status and, as I intend to set out in what follows, this is an essential element of the AIG's promotional strategy and major reason for the organisation's appeal.

\section{$\underline{\text { Between Online Charisma and Offline Worlds }}$}

An ethnographic study of Ken Ham's online teachings and activities suggests that he reflects many of the core characteristics of Weberian charisma. Here, I highlight 
three: (1) he offers his supporters the promise of salvation from an existential crisis; (2) he presents himself as an ordinary, yet idealised member of the community; (3) he relies on certain oratorical techniques for the communication of his ideas. Identifying these characteristics is the first goal of this article, but it is not the only one. It is not sufficient merely to recognise charisma when it appears online, but it behoves us to probe further and ask how charisma is constructed through the Internet, and how it is maintained.

Mindful of Weber's requirement that charisma inhabit the relationship between a leader and his followers, I therefore explore two contexts wherein Ham encounters the community of supporters that surrounds him. The first of these is through online exchanges on social media, where I show how Ham utilises the unique potential of the Internet for charisma's construction; the second is through indirect physical encounter, in followers' visits to the attractions in Kentucky. Both Creation Museum and Ark Encounter are heavily promoted by Ham in his online activities and are closely associated with his charismatic personality. In recognising the continuity between virtual and physical domains, I follow the consensus in much recent scholarship in digital anthropology, which is to "confound sharp boundaries between off-line and online contexts" (Colman 2010, 492). "i Rather than seeing clear categorical divisions between an individual's experiences via their online avatars and their experiences in the physical realities of daily life, I see these experiences as closely interwoven phenomena that occupy a single continuum (Srebarny and Khiabany 2010; Howard and Hussain 2013; Salvatore in Sadiki 2015). ${ }^{\text {vii }}$

Thus I propose that, while Ham demonstrates his charismatic qualification to some degree through his online manifestation and his virtual interactions with supporters, his claim to leadership is crucially supplemented by the activities of AIG in the physical world - namely the attractions in Kentucky that draw thousands of visitors each year (Bielo 2014 and forthcoming; Trollinger and Trollinger 2016). The bodily attendance of Ham's followers at these sites is, I suggest, a tangential extension of their engagement with him through virtual channels, and a necessary sign of their approval of his charismatic mission.

\section{Methodology: Digital Ethnography}


His prolific online presence makes a study of Ken Ham, and the community that surrounds him, highly suited to digital ethnography. Building on its heritage in the field of anthropology, digital ethnography - like its non-digital counterpart - relies on the construction of "thick description" (Geertz 1973) to provide detailed and situated accounts of day-to-day human experience (Beollstorff et al 2012; Pink et al 2015; Underberg and Zorn 2013). It is not necessarily concerned with the breadth of data that can be accumulated through online methods, but rather with providing due local context for the analysis of that data (Varis 2014:57).

Access to such vast repositories of data is not the norm for anthropologists working in non-digital contexts. A question therefore faces the digital ethnographer concerning which data to select for analysis, and which to pass by, and how to ensure balanced representation of one's ethnographic subjects in the process - a methodological dilemma that faces all fieldworkers, but which is exacerbated in scale in the digital context. For the present study, I have attempted to give equal weight to the three major digital platforms on which Ken Ham is operational, although my analysis concentrates on the dynamics specific to social media. The ethnographic data is taken from observations of approximately 250 of his digital contributions (videos, social media postings, and blogs) through archives as well as live feeds spanning a five and a half-year period from January 2012 to July 2017. The comments and responses of his supporters, as well as his detractors, were also observed.

Digital ethnography is set apart from its non-digital counterpart in that the ethnographer is able to observe social practices without being bodily present, or even visible, herself (Pink et al 2015; Varis 2014:62). In some ways, this is the ideal situation for the fieldworker, who is able to observe her informants like a 'fly on the wall', safe in the knowledge that her presence is not influencing or compromising their behaviour. ${ }^{\text {viii }}$ In my observations of Ken Ham and his followers, I have maximised this opportunity and been "present" in "live feed" sessions and other online spaces yet have not been an active participant in comment threads or other virtual conversations - thus retaining a kind of digital invisibility as an ethnographer. A word on ethics is necessary here. Unlike in face-to-face ethnographic encounters, I was unable to obtain permission to study my subjects. While acknowledging the 
ethnical dilemmas inherent in this situation, I maintain total anonymity in the text and do not reveal the online identities or genders of contributors.

In analysing Weber's idea of a bi-lateral charismatic "contract" between leader and followers, it would be apposite to also engage directly through "real-life" ethnography with Ham's supporters themselves (Bonilla and Rosa 2015; Juris 2012; Postill and Pink 2012). This would satisfy those voices arguing that "what is needed is not simply 'internet ethnography' but 'internet related ethnography' [...] that follows users across multiple online and off-line communities to better understand how digital and analog forms of engagement are mutually constitutive" (Bonilla and Rosa 2015:11). A secondary, offline ethnographic study would therefore be welcomed, in order to develop the argument put forward here, but it is primarily Ken Ham's online charismatic persona that is the object of enquiry in what follows.

\section{Existential Threat and Ham as Saviour Figure}

The message that Ken Ham communicates online is based on the bedrock of all charismatic leadership claims: the construction or identification of an existential threat in the minds of his followers. For Ham, this threat is located in the rise of moral relativism in American society, something that is causally linked to a decline in public performances of Christianity. This anxiety is articulated as a loss of "Biblical authority", and finds deep resonance with Ham's conservative evangelical constituency, providing fuel for the entire AIG project (Trollinger and Trollinger 2016). He explains this in a 2012 YouTube audio sermon, which at the time of writing has attracted 11,610 views:

Do you realise that when we're talking about the days of creation, we're talking about the authority of scripture? [...] At the very beginning of the Bible it says, "in the beginning God created the heaven and the earth'. And if that's not true then the rest of the Bible's not true. [...] When we take man's ideas outside the Bible and we add them to the Bible and re-interpret the Bible and say 'you don't have to take this as written', you unlock a door. And the door you unlock is you don't have to take the Bible as written, and you use man's ideas to interpret it - and subsequent generations will push that door further and further and further until you see a loss of Biblical authority. Tell me, do you see that in this nation? [...] I believe the six days of creation issue is one of the major reasons we see such a loss of Biblical authority in the whole western world today. ${ }^{\text {ix }}$ 
'Historical criticism' of the Bible emerged in the $19^{\text {th }}$ century, engaging a scriptural hermeneutic that was based primarily on exploring the historical and cultural context that influenced the text's human authors. The theological liberalism that it ushered in was a major driving force behind the genesis of Christian fundamentalism amongst US Protestants at the start of the $20^{\text {th }}$ century. For Ham, who follows in the fundamentalist tradition, a literalistic interpretation of the Bible - and specifically, the narrative of creation in the first chapters of Genesis - is the ultimate battleground between his conservative religious constituency and $21^{\text {st }}$ century secular, western culture (Harding 2001; Numbers 1993; Smith 2000, 2008). In the AIG creationist imaginary, evolutionary science is the immediate enemy, yet secular pluralism in $21^{\text {st }}$ century America is the broader existential threat. In response, Ham offers a kind of Weberian "salvation" to his followers through a literalistic reading of the Genesis account: if the Bible can successfully challenge modern scientific consensus and be "literally" correct on the issue of human origins, then surely - Ham argues - it is authoritative in every way, and can be mined for legal and ethical absolutes as well.

Support for this core element of his teaching is reflected in the online conversations that take place around Ham's social media contributions, and the format of these online discussions plays an important part in the construction of the charismatic community that surrounds him. In response to a lengthy Facebook posting by Ham in early 2017 that protested attitudes towards the Bible that regard it as neither literal nor infallible, nine comments (all positive) were submitted by Ham's supporters, including the following two: "Christians are too eager to accept any and all versions of the Bible!!! God's Word never changes!!!”; and, “The Bible teaches us how we should behave, and that's not what some people want to believe." ${ }^{x}$ Another post, beginning "When our culture rejects God's Word as absolute authority, 'truth' is subjective..." attracted over 1,000 'likes' and nearly 400 'shares': 
When our culture rejects God's Word as absolute authority, "truth" is subjective -- man makes himself the ultimate authority -- it doesn't work. Subjective moral truth cannot work in any society. Someone ends up deciding truth, and usually it's those with the most power or money.

Objective truth exists because we have God's Word. In the Gospel of John, Jesus says, "Sanctify them by Your truth. Your word is truth" (John 17:17). A biblical worldview stands in sharp contrast to our culture's thinking. Don't get caught in post-truth thinking -- immerse yourself in God's truth.

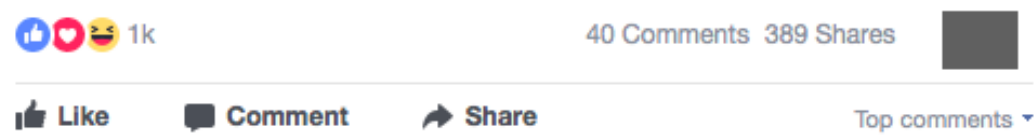

Ken Ham official Facebook feed, 3 March 2017. Original post made at 10.00.

The facility on social media to 'like', 'share' and voice agreement and disagreement allows for allegiances to be clearly displayed in a way that is not easily replicated in offline social encounters. ${ }^{x i}$ Responses to comments that are critical of Ham tend to result in retorts by followers that are "liked" by many others, and have the effect of consolidating support around him. It is not only Ham himself who can witness this consumption and defence of his views by his supporters, thus bolstering his charismatic mandate; the community itself is also witness to the same endorsements, and in so doing it cements its sense of common identity. Comments are not anchored in a particular time or place, as social media offers an archive service. Online discussions continue to exist in the virtual realm long after they were first written, with the potential to attract future interest from visitors to (or followers of) Ham's account.

In negotiating a binary discourse of danger and salvation, Ham constructs clearly identifiable categories. Those who oppose his message are collectively labelled "the secularists". This group, which is imagined as an organised and homogeneous force wilfully opposing the "truth" proclaimed by the Bible, is castigated in Ham's online messages at every turn. Secularists are frequently accused of deliberately misinterpreting evidence to suit their own ends, as on Twitter on 8 December 2016 when Ham declared that, "Secularists claim they want evidence - but most don't they just reinterpret it based on their religion - they are willfully ignorant." ${ }^{x i i}$ In 
response to a news story about a Kentucky Governor who declared 2017 the "Year of the Bible", he announced on Facebook on 4 January 2017 that, "intolerant secularists are already complaining as they want to eliminate the Bible and impose their no God religion on the culture."xiii The post attracted 3,100 'likes' and fifty comments, the great majority of which affirmed Ham's statement and attracted further 'likes' of their own.

The binary categories that Ham delineates between secularists and his vision of the Christian faithful constitute an important component of his online charismatic project. The Internet provides a kind of moral "free space" where the norms of inter-personal interaction are in many ways suspended, and beliefs and opinions can be expressed without fear either of social reprisal or the discomfort associated with the shattering of social taboos in real life (Phillips 2015; Turkle 2011). Hence the emergence of Internet 'trolls' in recent years: individuals who operate online outside the parameters of established social nicety and convention. The digital environment has a similar catalytic effect on Ham's polarizing discourse surrounding secularists on the one hand and Christian believers on the other. It is relatively easy for Ham to make dogmatic and sensational statements about his perceived antagonists from the "safety" of virtual media, particularly when they are of a kind which require considerable unpacking in response: what is in fact meant by a secularist, for example, and why is the category necessarily considered wholly at odds with religious faith? Is Ham invoking secularism as a synonym for atheism? Rather than providing an effective forum for the discussion of these issues, online media - and social media in particular - can frame the issues in simplistic sound-bites that are difficult to refute on their own terms. In turn, followers are invited to consume these sound-bites of knowledge rather than necessarily to test them, and in this way existing in-group identities are further solidified in the face of perceived hostility from without (Pariser 2012).

\section{Ham's Image as Idealized Christian Male}

In Weber's formulation, charisma is defined in part by a leader's ability to demonstrate empathy and commonality with their followers, while at the same time embodying legendary or even mythical status. Such leaders must on the one hand "present themselves as ordinary men, merely obeying the wishes of the people" while 
recognizing that "the charisma of this type of leaders may [...] depend upon their becoming assimilated, in the thought and feelings of a populace, with its sacred figure or heroes." (Stutje 2012, 8). Charisma, in other words, is dependent for its survival on a leader's capacity to embody a lofty ideal that his/her followers aspire to, in a manner that simultaneously supports the impression of their accessibility.

Ken Ham achieves this online by projecting a highly idealised kind of evangelical masculinity primarily through the medium of digital photography and video. The core components of Ham's evangelical identity which are transmitted through these visual media are: modest dress and personal comportment; and public displays of conservative morality, expressed most forcefully with reference to marital faithfulness and shared Christian values within the nuclear family. Ken Ham's family embodies his message of conservative morality, serving as an idealised representation of the Christian life, ${ }^{\text {xiv }}$ and features intermittently across the spectrum of social media platforms on which he is active.

On 29 December 2016, for example, his regular blog on the AIG website was entitled "Family Photos and 12 Stones of Remembrance", xv and featured photographs of Ham and his wife along with each of their five children posing for the camera outside Ark Encounter with their respective spouses and children (see images below). The photographs, which revere the heterosexual nuclear family unit, serve as visual and embodied representations of the conservative vision for American society that Ham articulates in his sermons and teachings. In this way, Ham enacts an aspect of Weberian charisma expounded by Cavalli, who observes that, "for the average person, the cause itself does not exist independently from the leader. The leader embodies it, together with the hope of its future implementation." (Cavalli 1986, 68). 


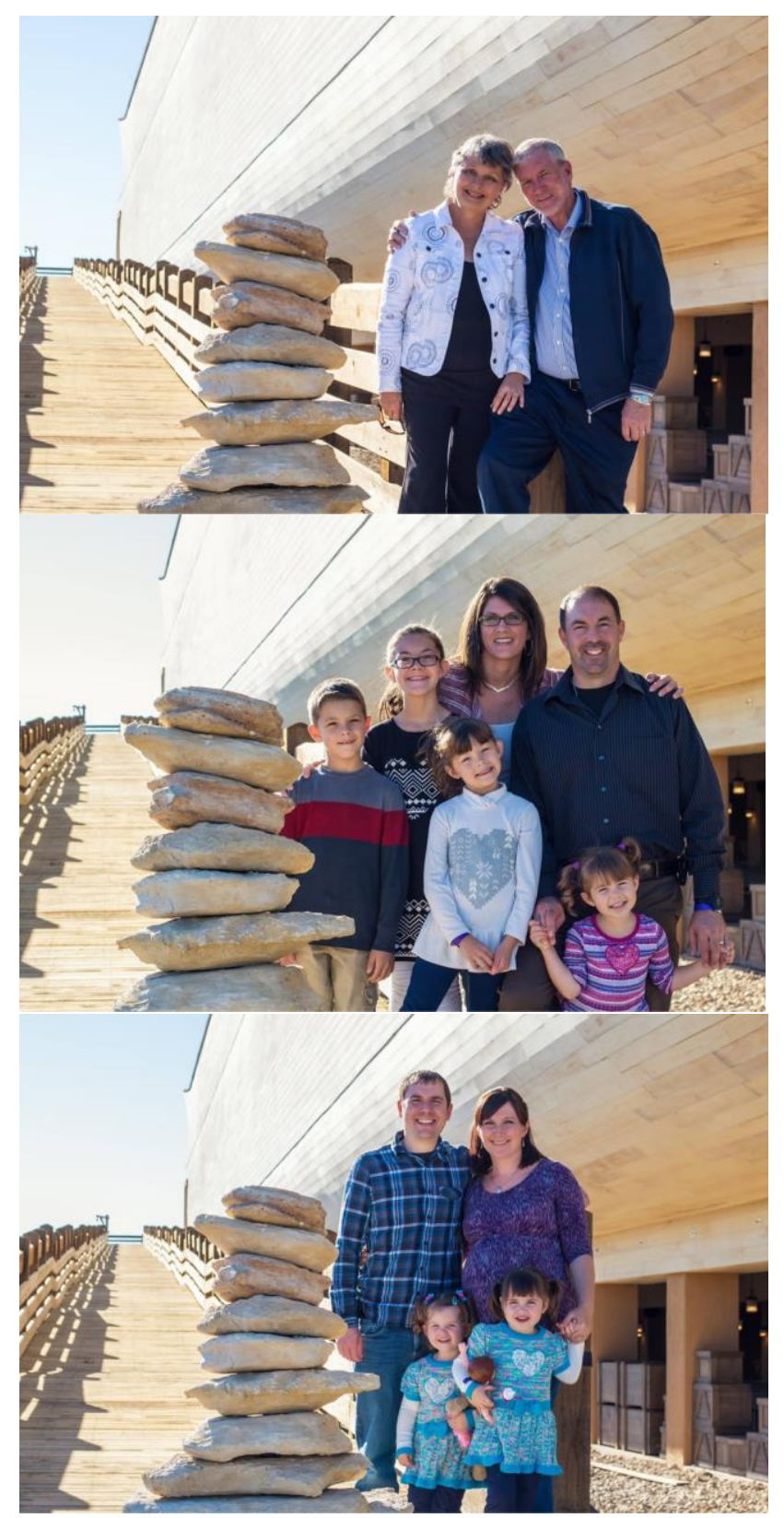

Top: Ken Ham with his wife, Mally, at Ark Encounter. Middle and bottom: Two of Ham's five children with their spouses and children.

These kinds of online performances of conservative Christian family values are met with warm approval amongst Ham's followers. ${ }^{\text {xvi }}$ On 29 December 2016, Ham's Facebook feed showed a photograph of himself with his wife, along with the following text:

It's December 30 in Australia, and 44 years ago on this day I married a beautiful young lady called Mally [...] 44 years later we have 5 godly children ( 1 is single) with 4 godly spouses, and 15 ( +1 on the way) grandchildren who are all being trained as the Bible instructs. Praise the Lord. ${ }^{\text {xvii }}$ 
The post attracted 4,200 "likes" and 326 "comments" from followers, mostly offering warm congratulations. ${ }^{\text {xviii }}$ Ham's status updates - which serve most commonly to express Ham's opinions on evolution and secularism, provide general social commentary, and publicise the Creation Museum and Ark Encounter - normally attract substantially fewer; on average between 200 and 1,500 "likes". Visual windows into Ham's personal life, which confirm his own conservative family values, clearly find deep resonance amongst his followers. It is highly significant that Ham's own children and grandchildren are known (and, indeed, seen) to be "godly", a term which here denotes public conformity to clearly delineated evangelical values. Online media provide a valuable conduit for the construction of charisma in this area because of the communicative potential of digital imagery: photographs of Ham's idealised family can be displayed and archived for followers to access repeatedly, and can easily be propagated by followers "sharing" them with wider networks of contacts.

Ken Ham's online persona is at once familiar and mythical, very much in the way outlined by Weber. Followers may relate personally to performances of conservative Christianity depicted in his digital photographs, for these are the values they themselves likely strive to live by. At the same time, Ham is a kind of "sacred figure" because he and his family are the visual representation of the normative ideal. In these online scenarios, Ham himself represents an idealised masculinity that relies on conservative notions of Biblical headship and complementarianism ${ }^{\mathrm{xix}}$ in gender roles. Ham's wife, for example, does not have an independent online presence and - apart from her authorship of three creationist colouring books for children - appears only as an occasional consort to Ham. Here there is clear continuity between Ham's personal life and his ministry at AIG where, in line with conservative Christian theology, women are active mainly in support roles and fifteen of sixteen core speakers are male. ${ }^{x x}$

\section{Ham as Digital Orator}

According to Weber, charisma leans heavily on the impressive personal presence, or magnetism of the leader and particularly on well-honed oratorical skills through which they are able to convey their mission to their followers. Voice is important, because charisma cannot be transmitted through the written word but is instead an aural experience (Welskopp in Stutje 2012). Ham's voice is a significant part of his 
online persona, and his followers hear it often. His sermons and public debates are accessible in audio visual form on YouTube and the AIG website, and he makes frequent use of the "go live" option on Facebook - whereby Ham talks directly to the camera, while navigating and commentating on background activities at AIG attractions. Significantly, he also has a daily radio show, which is broadcast across the USA by over seven hundred local radio stations.

In his recorded sermons and messages, Ham evidences a typically Protestant emphasis on the spoken and written word as a primary medium of communication. In this sense, he illustrates the point made by Susan Harding in her study of the fundamentalist preacher Jerry Falwell, where it is observed that, 'much collective ritual among orthodox Protestants is likewise centred on words, on the Word.' (Harding 2000: 37). Harding talks here about the language of preachers from this tradition being 'intensified, focused, and virtually shot at the unwashed listener'. Ham evidences the same techniques, having a rhetorical style that is stripped of nuance or subtlety. Indeed, he relies on the same 'formalized rhetorical techniques' (ibid) that Harding identifies with respect to Falwell. Ham's oratorical strategies rely on the repetition of certain key tropes, which are simple and well rehearsed. Many of them rely on basic and somewhat over-simplified binary oppositions: word of God and word of man; secular worldview and Biblical worldview; observational science and historical science. ${ }^{x i}$ Interestingly, these dual tropes also organise the physical space of the Creation Museum and Ark Encounter, and thus Ham's oratorical strategies blend into, and are reinforced by, the material culture of the museum sites. In oratory, the three binary tropes are repeated over and over, and are articulated with absolute confidence and an intonation that suggests that what Ham is saying ought to be obvious. The ontological premise that underpins all of Ham's oratory is that the Bible is literally authoritative on every subject, and this uncomplicated hermeneutic is reflected in the studied simplicity of Ham's rhetoric.

A key aspect of Ham's oral delivery that is noteworthy, and which lends his performance a charismatic quality, is his distinctive accent (Trollinger and Trollinger 2016; Welskopp in Stutje 2012). Ham's Australian intonation provides a constant reminder of his "exceptional" status, according to which he is - as Weber indicated "set apart from ordinary men". The story of Ham's arrival in the USA as a "creation 
missionary" is one that he tells numerous times, and is available in its entirety on the AIG website. ${ }^{x x i i}$ Weber identified a sense of calling, or mission, as one of the principal drivers behind charismatic leadership, and Ham's decision to leave the country of his birth and move to the USA with a missionary calling is therefore significant. In presenting himself to his online followers in the USA through audiovisual channels using the medium of the spoken word, Ham constantly affirms and reaffirms - through his accented English - his liminal status. Thus in the act of oratory, Ham's voice becomes the living articulation of his missionary project.

Audio-visual media such as YouTube and Facebook, and particularly live streaming platforms such as Facebook's "go live" function, foreground oral performance over the written word and therefore represent ideal channels for the transmission of charisma through the human voice (Welskopp in Stutje 2012). Live streaming is a particularly potent medium as it allows listeners to interact with presenters in real time. This function provides a context for the construction of new (temporary) virtual charismatic communities. Ham's live feeds vary in content but are usually filmed at the AIG headquarters, ensuring a direct association between his charismatic person and the Kentucky sites - an association that I will return to below. Content ranges from conversations between Ham and particular employees at AIG, when viewers are invited to contribute questions in the live comments section, to more unstructured activities such as Ham strolling around the sites and delivering an informal monologue to the camera. In these cases, followers offer him greetings and statements of appreciation for his work, and are invited to identify the location from which they are watching. The result is an opportunity for followers to participate in a geographically dispersed digital community, rotating for a fixed time around the charismatic person - and voice - of Ken Ham. Accordingly, Ham becomes the centre point of an 'imagined' creationist community, which exists through virtual networks rather than face-to-face encounter (Anderson 1983). 


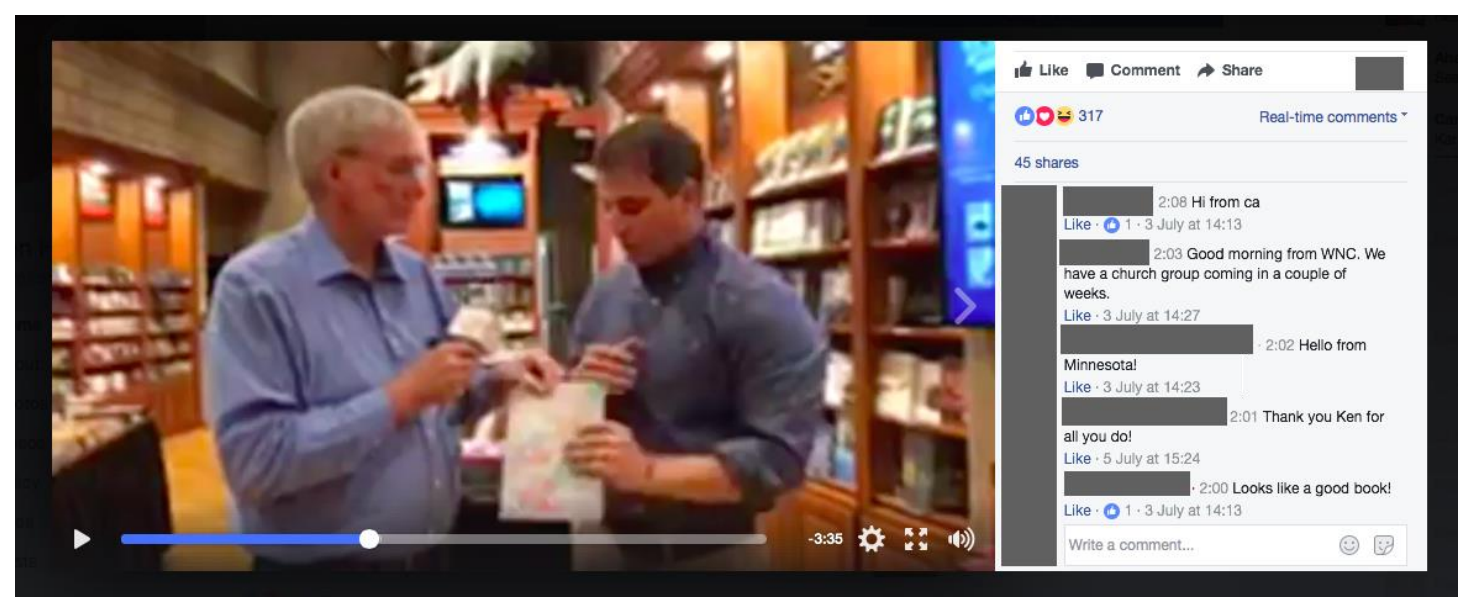

Ham (left), speaking to a colleague in the bookshop at the Creation Museum during a "go live" session on Facebook.

The Physical Sites in Kentucky and "Material Charisma"

Up until this point, I have shown how Ken Ham's online persona reflects three of the core characteristics of Weberian charismatic leadership, and how digital media serves as a particular conduit for encounters with his followers and for the transmission and affirmation of charisma, which in turn sustains Answers in Genesis. Yet unlike some other online religious and/or activist communities, AIG is not confined to the digital sphere; it also inhabits a physical geography. The Creation Museum and Ark Encounter attractions in Kentucky serve in a practical sense as its organisational headquarters, and they are also a crucial part of the charismatic project. The figures are significant: 2 million people visited the Creation Museum in its first six years of operation (2007-2013); ${ }^{\text {xiii }}$ Ark Encounter was projected to see 1.2 million visitors in its first year (2016-17). Thus the recognition that Ham receives through online channels is significant, but it is neither the only forum in which he is active, nor the only way in which his mission attracts the affirmation it requires in order for him to continue under the charismatic mantle. The bodily attendance of his followers at AIG attractions serves as further confirmation of their approval. There is considerable fluidity between the two spheres, as followers who have visited the Kentucky sites feed regularly into online conversations, where they invariably give positive testimonies about their museum visits, thus continually generating more interest in the sites within the digital community. 
The Creation Museum and Ark Encounter lie at the heart of the extensive commoditisation of Ham's creationist ideology. They are aggressively promoted by Ham online: advertisements for the museum attractions, and periodic special offers for discounted admission, are almost always foregrounded either at the beginning or the end of his online sermons, as well as on Facebook and Twitter. Followers are also informed about onsite restaurants, the AIG store and even details about the cost of parking - such that monetary matters and consumerist concerns are regularly and explicitly foregrounded. Followers are also frequently encouraged to purchase AIG products online - namely books, resources for home-schooling, and full DVD recordings of Ham's teachings and public debates.

These products would not hold the same appeal if they were not associated with the charismatic personality of Ken Ham. The construction of charisma online therefore enables Ham and his associates at AIG to successfully market offline services and products, and to generate sizeable revenue. This commoditisation operates in a circular fashion, and serves an important purpose in sustaining Ham's charismatic claim: in purchasing AIG products and experiences, Ham's followers attest to the validity of his mission through the exchange of their money for his commoditised ideas, and as a result, the AIG project flourishes and expands. This expansion is subsequently interpreted as "blessing" from God and as evidence of the validity of Ham's mission and his spiritual "calling", thus attracting further interest. ${ }^{\text {xxiv }}$

In all of his online activities, Ken Ham maintains a direct personal association with the museum sites in Kentucky. Importantly, he is often seen to be physically present at them: in the expansive "photographs" section of Ham's official Facebook page, in approximately $80 \%$ of the images he is depicted at either the Creation Museum or Ark Encounter. Most of his preaching videos are also filmed there, along with (as discussed above) almost all his live feeds. For his supporters who have encountered Ken Ham online before visiting Kentucky, there is therefore an implicit synergy between the museum sites and the charismatic person of Ham himself. We can speak, then, of a kind of deflected charisma wherein the person of Ham serves as a kind of online portal to the AIG attractions, which are imbued by association with "charismatic materiality". Visitors to the museum sites are unlikely to personally meet 
Ham himself, but may encounter charisma indirectly in the material sites that his ideas inhabit.

\section{Concluding Remarks}

A close analysis of Ken Ham and the community that surrounds him reveals much about the function and potential of charisma in a digital age. Weber posited that charisma is located in the bi-lateral relations between a leader and their followers, and that it relies on the continual endorsement of followers in order to survive. In the digital context, the parameters of human encounter are re-defined and relative anonymity replaces face-to-face interaction. These new conditions do not, however, appear to preclude the creation and maintenance of charisma; rather, they offer new avenues for its demonstration, endorsement and propagation that are specific to the digital environment.

Ken Ham's use of social media sound bites, digital photography and audio-visual media allow him to accumulate a wide virtual following that is sympathetic to his creationist cause. At the very centre of this 'imagined community' of followers stands the personality of Ham himself, whose charismatic claim is routinely endorsed by supporters through their digital interactions with him and with one another. Messages of support and even adulation are frequently forthcoming through these online channels, and the voices of detractors appear only to consolidate Ham's followers in his defence. The charismatic project transfers to offline worlds through visits to the museum sites in Kentucky, where endorsement of Ham translates into income revenue for AIG that is subsequently interpreted as a 'sign' of divine approval, and a mandate to continue its work.

Weber has given us a theoretical framework for recognising charisma and understanding the mechanisms through which it is able to operate. It behoves us, however, to turn back to Susan Harding and her analysis of Protestant fundamentalism in order to situate Ham as a charismatic leader in the very specific cultural and religious milieu within which he operates. Harding has observed that 'fundamental [...] interpretation rests of a poetics of faith - absolute faith - not a hermeneutics of suspicion' (Harding 2000:88). By extension, Harding argues that the inerrancy that is ascribed to the Bible in fundamentalist circles can also be attached to 
preachers and 'men of God' like Ham, in such a way that his message - in all of its rhetorical and intellectual simplicity - is accepted with the considerable potency and heft of religious truth. When combined with the mobilisation potential of the Internet, the impulse towards commodification and the opportunities of a free market economy, this 'poetics of faith' can manifest itself in ways that Ham's pre-digital forebears would surely have found hard to imagine.

\section{$\underline{\text { Disclosure Statement }}$}

No potential conflict of interest was reported by the author.

\section{Acknowledgements}

This work was supported by the Templeton World Charity Foundation under Grant 0103. I am grateful to Sarah Winkler-Reid and Hilary Marlow for their comments on an earlier version of the manuscript, and to the two anonymous peer reviewers for their insightful critiques.

\section{$\underline{\text { References }}$}

Berkman, Michael, and Eric Plutzer. 2010. Evolution, Creationism and the Battle to Control America's Classrooms. Cambridge: Cambridge University Press.

Bielo, James S. Forthcoming (2018). Ark Encounter: The Making of a Creationist Theme Park. New York: New York University Press.

Bielo, James S. August 2014. "Making a Biblical Theme Park." The Immanent Frame.

Bielo, James S. 2009. Words Upon the Word: An Ethnography of Evangelical Group Bible Study. New York: New York University Press.

Blanton, Anderson. 2015. Hittin' the Prayer Bones: Materiality of Spirit in the Pentecostal South. Chapel Hill: University of North Carolina Press.

Boellstorff, Tom. 2012. "Rethinking Digital Anthropology." In Digital Anthropology, edited by Heather Horst and Miller. London and New York: Berghahn.

Boellstorff, Tom, Bonnie Nardi, Celia Pearce, and T.L. Taylor. 2012. Ethnography and Virtual Worlds: A Handbook of Method. Princeton, New Jersey: Princeton University Press.

Bonilla, Yarimar, and Jonathan Rosa. February 2015. "Ferguson: Digital Protest, Hashtag Ethnography, and the Racial Politics of Social Media in the United States." American Ethnologist 42, no. 1: 4-17.

Brasher, Brenda E. 2001. Give Me That Online Religion. New York: John Wiley \& Sons, Inc.

Campbell, Heidi A., ed. 2013. Digital Religion: Understanding Religious Practice in New Media Worlds. London and New York: Routledge.

Cavalli, Luciano. 2012. "Charismatic Domination, Totalitarian Dictatorship, and Plebiscitary Democracy in the Twentieth Century." In Changing Conceptions of Leadership, edited by C.F. Graumann and S. Moscovici. New York: Springer-Verlag. Derman, Joshua. 2012. Max Weber in Politics and Social Thought. Cambridge: Cambridge University Press. 
Eade, John, and Sallnow, Michael J., eds. 1991. Contesting the Sacred: The Anthropology of Pilgrimage. Urbana and Chicago: University of Illinois.

Freund, Peter E.S. December 2009. "Social Synaesthesia: Expressive Bodies, Embodied Charisma." Body and Society 15, no. 4.

Georgakopoulou, Alexandra, and Tereza Spilioti. 2015. The Routledge Handbook of Language and Digital Communication. Abingdon: Routledge.

Gerth, H.H., and C Wright Mills, eds. 2009. Max Weber: Essays in Sociology. London and New York: Routledge.

Gillespie, Marie, David Eric John Herbert, and Anita Greenhill, eds. 2013 Social Media and Religious Change. Berlin: de Gruyter.

Harding, Susan. 2000. The Book of Jerry Falwell: Fundamentalist Language and Politics. Princeton: New Jersey: Princeton University Press.

Howard, Philip N., and Muzammil M. Hussain. 2013. Democracy's Fourth Wave? Digital Media and the Arab Spring. Oxford: Oxford University Press.

Howard, Robert Glenn. 2011. Digital Jesus: The Making of a New Christian Fundamentalist Community on the Internet. New York: New York University Press.

Joosse, Paul. 2014. "Becoming a God: Max Weber and the Social Construction of Charisma." Journal of Classical Sociology 14, no. 3: 266-283.

Juris, Jeffrey S. 2012. "Reflections on \#Occupy Everywhere: Social Media, Public Space, and Emerging Logics of Aggregation.” American Ethnologist 39, no. 2: 259-79.

Lash, Scott, and Sam Whimster. 1987. Max Weber, Rationality and Modernity. New South Wales: Allen and Unwin.

Lindholm, Charles. 1990. Charisma. Oxford: Blackwell.

Lindholm, Charles. 2013. The Anthropology of Religious Charisma: Ecstasies and Institutions. New York: Palgrave Macmillan.

McCalla, Arthur. 2013. The Creationist Debate: The Encounter between the Bible and the Historical Mind. 2nd ed. New York and London: Bloomsbury Academic.

Numbers, Ronald L. 1993. The Creationists: The Evolution of Scientific Creationism. Oakland, CA: University of California Press.

Pariser, Eli. 2012. The Filter Bubble: What the Internet Is Hiding from You. London and New York: Penguin.

Phillips, Whitney. 2015. This Is Why We Can't Have Nice Things: Mapping the Relationship Between Online Trolling and Mainstream Culture. Cambridge MA and London: The MIT Press.

Pink, Sarah, Heather Horst, John Postill, Larissa Hjorth, Tania Lewis, and Jo Tacchi. 2015. Digital Ethnography: Principles and Practice. California: Sage.

Postill, John, and Sarah Pink. 2012."Social Media Ethnography: The Digital Researcher in a Messy Web." Media International Australia 145: 123-34.

Potts, John. 2009. A History of Charisma. London and New York: Palgrave Macmillan.

Roth, Guenther, and Claus Wittich, eds. 1968. Max Weber: Economy and Society. Oakland, CA: University of California Press.

Salvatore, Armando. 2015. "A Public Sphere Revolution? Social Media versus Authoritarian Regimes." In Routledge Handbook of the Arab Spring: Rethinking Democratization, edited by Larbi Sadiki. Abingdon: Routledge.

Schjoedt, Uffe, Hans Stodkilde-Jorgensen, Armin W. Geertz, Torben E. Lund, and Andreas Roepstorff. January 2011. "The Power of Charisma - Perceived Charisma Inhibits the Frontal Executive Network of Believers in Intercessory Prayer." Social, Cognitive and Affective Neuroscience 6, no. 1. 
Singler, Beth. 2017. "No Leader, No Followers: The Internet and the End of Charisma?" In Visioning New and Minority Religions: Projecting the Future, edited by Eugene V.

Gallagher. Abingdon: Routledge.

Smith, Christian. 2008. American Evangelicals: Embattled and Thriving. Chicago: University of Chicago Press.

Smith, Christian. 2000. Christian America?: What Evangelicals Really Want. Oakland CA: University of California Press.

Sreberny, Annabelle, and Gholam Khiabany. 2010. Blogistan: The Internet and Politics in Iran. London: I.B. Tauris.

Stutje, Jan Willem, ed. 2012. Charismatic Leadership and Social Movements: The Revolutionary Power of Ordinary Men and Women. Oxford and New York: Berghahn.

Swatos, William, and Tomasi, eds. 2002. From Medieval Pilgrimage to Religious Tourism: The Social and Cultural Economics of Piety. Westport, CT: Greenwood.

Trollinger, Susan L, and William Vance Trollinger. 2016. Righting America at the Creation Museum. Baltimore: Johns Hopkins University Press.

Turkle, Sherry. 2011. Alone Together. New York: Basic Books.

Turner, Bryan. 2013. The Religious and the Political: A Comparative Sociology of Religion. Cambridge: Cambridge University Press.

Underberg, Natalie M., and Elayne Zorn. 2013. Digital Ethnography: Anthropology, Narrative and New Media. Austin: University of Texas Press.

Varis, Piia. 2015. "Digital Ethnography." In The Routledge Handbook of Language and Digital Communication, edited by Alexandra Georgakopoulou and Tereza Spilioti. Abingdon: Routledge.

\footnotetext{
${ }^{\mathrm{i}}$ www.herkul.org

ii A notable exception is the scholarship on New Religious Movements, (Palmer 2004; Singler 2017).

iii Jonathan P. Hill (2014), National Study of Religion and Human Origins.

https://biologos.org/uploads/projects/nsrho-report.pdf (accessed 27 February 2018).

${ }^{\text {iv }}$ On the psychological dimensions of charisma, see Schjoedt et.al. (2011) or Freund (2009).

${ }^{v}$ All figures in this paragraph correct on 23 October 2017.

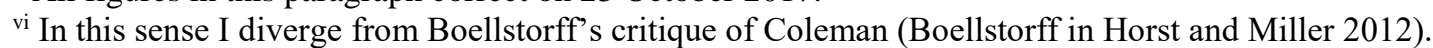

vii During the so-called Arab Spring of 2010-2012, dissenting online communities fed directly into real life street protests. See Howard and Hussain (2013).

viii Some scholars have argued that this kind of observational approach, stripped of its participatory aspect, does not constitute 'true' ethnography (Varis 2015). I have deliberately forsaken it here in order to exploit the potential of invisibility.

ix 'Six Days of Creation and Biblical Authority'. Audio sermon uploaded to YouTube, 2 March 2012. https://www.youtube.com/watch?v=LovsSAcfz8w (accessed 27 February 2018).

${ }^{\mathrm{x}}$ Ken Ham official Facebook feed, 23 January 2017. Original post made at 15.08.

${ }^{x i}$ Individual comments from followers are not given or analyzed here for reasons of preserving anonymity.

xii Ken Ham official Twitter feed, 8 January 2017 at 05.56.

xiii Ken Ham official Facebook feed, 4 January 2017 at 22.02.

xiv There is a certain dynastic element to Ham's leadership, and various members of his immediate family are actively involved in the work at AIG.

${ }^{\mathrm{xv}}$ https://answersingenesis.org/blogs/ken-ham/2016/11/29/family-photos-and-12-stones-remembrance (accessed 27 February 2018).

xvi They also sometimes garner criticism. One follower responded negatively to two posts by Ham on 1 and 2 February 2017 in which he (Ham) mocked a call to substitute the term "expectant mothers" with "pregnant people" in order to accommodate transgender people. Ham's comment was framed by two photographs of a grandson and a granddaughter, and the statement that "there's a difference between boys and girls!". This otherwise faithful follower accused Ham of homophobic dogmatism, and of
} 
"using [your] family to promote an agenda". They were quickly reprimanded by Ham himself, as well as by fifteen other followers.

xvii Ken Ham official Facebook feed, 29 December 2016 at 22.00.

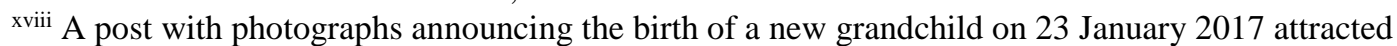
even more: 6,500 "likes".

xix The theological belief that men and women have different, but complementary, roles in family life and religious leadership.

${ }^{x x}$ https://answersingenesis.org/bios (accessed 27 February 2018).

${ }^{x x i}$ Ham teaches that only science that can be empirically tested in the present day is valid, and he therefore rejects paleoarcheology and other sciences that study deep time.

xxii ‘Ken Ham’s Personal Testimony: A Fire in My Bones'. https://answersingenesis.org/bios/ken-ham (accessed 27 February 2018).

xxiii Introduction to 'Bill Nye Debates Ken Ham (Official)' at

https://www.youtube.com/watch?v=z6kgvhG3AkI (accessed 27 February 2018).

xxiv See Ham's blog entry on 31 December 2016, entitled '7 Ways God Blessed Answers in Genesis in 2016'. https://answersingenesis.org/blogs/ken-ham/2016/12/31/7-ways-god-blessed-answers-ingenesis-in-2016 (accessed 27 February 2018). 